\title{
Entre a cruz e a espada religião, política e controle social nas Minas do Ouro (1693-1745)*
}

\author{
The cross and the sword \\ religion, politics and social control in the \\ golden captaincy of Minas Gerais (1693-1745)
}

\author{
RENATO DA SILVA DIAS \\ Doutor em História pela UFMG \\ Professor do Departamento de História da UNIMONTES \\ Av. Dr. Rui Braga, $s / n^{\circ}$, Vila Mauricéia \\ Montes Claros/ Minas Gerais \\ dias.reno@gmail.com
}

RESUMO O objetivo central deste artigo é tratar das implicações políticas concernentes à implantação do catolicismo no hinterland mineiro, em sua fase de organização (1693-1745), assinalando as principais dificuldades encontradas pela coroa para estabelecer a vida religiosa nesse território. Percebe-se que o político não pode ser esquadrinhado somente em seu registro mais aparente, uma vez que ele também jaz em causas mais profundas que se radicam no imaginário religioso. Destarte, diante da complexidade do "real", torna-se necessário verificar as suas mediações, seus limites e o coeficiente de dependência/independência entre essa instância e o religioso. A análise do político via "questão religiosa" demanda reflexão e esforço maiores para se entender os homens em seu próprio tempo, como agentes sociais ativos, embora muitas vezes atuando sob circunstâncias extremamente adversas. Para tal, este estudo se realizou à luz da documentação coeva, notadamente aquela produzida pela Secretaria do Governo.

Artigo recebido em: 18/08/2009. Aprovado em: 10/11/2009. 
Palavras-chave religião, política, resistência, Minas Gerais

ABSTRACT This paper focuses on the political implications regarding the Catholicism implementation in the hinterland of the gold captaincy of Minas Gerais-Brazil, during its organization (1693-1745), empathizing the main difficulties faced by the Portuguese crown in order to establish the religious life in this territory. The political aspect can not be investigated only in its more apparent record, since it also lays on more profound causes rooted in the religious imagery. Consequently, before the "real" complexity, it became necessary to verify its mediations, limits and the dependence/independence coefficient between this instance and the religious facet. The analysis of the political aspect via "religious issue" demands further effort and reflection in order to understand men in their own time, as active social agents, although many times they act under extremely hard circumstances. To do so, this study is conducted in the light of the coeval documentation, especially that recorded by the Government Office.

Keywords religion, politics, resistance, Minas Gerais

Concomitantemente ao processo de normatização da sociedade mineradora, através da instalação do aparato administrativo-militar e de uma legislação que definia padrões de conduta e limites para o uso da força e coerção, ${ }^{1}$ a ordenação das Minas setecentistas também se desdobrou em outra frente: a organização da vida religiosa.

A notícia da descoberta de aluviões auríferas nas minas dos Cataguás e sertões do Caeté, em finais do século XVII, despertou a cobiça dos colonizadores que, de diversos pontos da América portuguesa, e de Portugal, acorreram prontamente a essas paragens. ${ }^{2}$ Após a ocupação das terras minerais e das áreas de criação de gado, assistiu-se à gênese das elites locais, que formavam, no mais das vezes, um poder violento e disposto a enfrentar o mando régio que então se instituía. Eram os famigerados potentados que se amotinaram em diversas ocasiões, indício de que poderiam desejar a independência da região. ${ }^{3}$ Tornava-se, pois, necessária

1 WEBER, Max. Economia e sociedade. Brasília: EdUnb, 2000. Observe, neste caso, a aplicação das Ordenações Filipinas e de leis extravagantes, através de bandos, cartas régias, alvarás, petições, etc.

2 BOXER, Charles R. A idade de ouro do Brasil: dores de crescimento de uma sociedade colonial. São Paulo: Cia. Editora Nacional, 1969

3 Sobre os potentados mineiros, conferir ANASTASIA, Carla Maria Junho. Vassalos rebeldes: violência coletiva nas Minas na primeira metade do século XVIII. Belo Horizonte: C/Arte, 1998; ANASTASIA, Carla Maria Junho. A geografia do crime: violência nas Minas setecentistas. Belo Horizonte: Editora UFMG, 2005; FIGUEIREDO, Luciano Raposo de A. Furores sertanejos na América portuguesa: rebelião e cultura política no sertão do Rio São Francisco, Minas Gerais (1736). Oceanos, Lisboa, n.40, p.128-144, out./dez. 1999. 
a aplicação de todas as formas possíveis para o controle e organização do corpus social, como a fundação das vilas, a implantação da justiça e, acreditava-se, o controle pela religião. ${ }^{4}$

De forma mais explícita, e a título de exemplo, pode-se citar a carta enviada ao rei pelo governador dom Pedro Miguel de Almeida Portugal (conde de Assumar), na qual apresentou sua consternação diante da desordem da religião nos altiplanos mineiros. Para "emendar" os eclesiásticos, o conde não viu outra solução senão instar ao rei a nomeação de um bispo missionário. Além disso, em caráter emergencial, requisitou a vinda de doze jesuítas, isto porque, naquela região:

Os males vão crescendo na medida do aumento destes povos já bárbaros pela grande distância em que estão do seu soberano e pela vastidão do país, e numa profecia nas primeiras pedras que lançou para o edifício da república romana achou que melhor freio para povos rebelados era inspirar Ihe Religião quando a não tinha, e com muita mais razão se pode esperar que estes se domestiquem por que já a tem suposta que na idéia, e não na prática; a objeção que a isto se oferece é a maior despesa que acresce a fazenda de V. Majestade mas se este motivo é o suficiente para que se devem de aplicar os meios precisos para o bem interior da consciência dos povos (sic). ${ }^{5}$

Como se pode apreender pelo conteúdo da carta, Assumar percebia a religião como um instrumentum regni, mecanismo apaziguador das tensões sociais em regiões de "fronteira aberta" e distantes dos olhos do rei.

Quase vinte anos depois, em 1738, os oficiais da câmara de Vila Rica relataram ao soberano que as irmandades da freguesia de Nossa Senhora da Conceição de Antônio Dias haviam se recusado a participar da procissão de Corpus Christi, o que, para as autoridades, resultaria não somente na diminuição do culto divino, mas também em escândalo para os fiéis. Cientes do desvelo da alteza real em fazer "crescer a veneração ao sacramento", e "sendo a causa da Religião e do divino culto a primeira base de toda a Monarquia", os vereadores rogaram a sua majestade que ordenasse às irmandades para acompanharem a procissão durante as cerimônias, como era de costume. Como se vê, a religião não apenas era posta como forma de controle político, mas como sustentáculo de toda a monarquia; ${ }^{6}$ e disso sabiam os príncipes, como já enfatizara dom João V, em missiva dirigida ao

4 António Manuel Hespanha e Maria Catarina Santos acreditam que: "O império português vai beneficiar ainda para sua implantação, da cooperação activa de um outro poder " a Igreja. Trata-se, portanto, de um outro tipo de domínio distinto do domínio político formal, e provavelmente mais presente, mesmo onde o poder político oficial não tinha condições para se implantar". HESPANHA, António Manuel e SANTOS, Maria Catarina. Os poderes num império oceânico. In: MATTOSO, José. (dir.) História de Portugal. Lisboa: Editorial Estampa, 1993, v.4, p.408. (Grifo nosso).

5 Belo Horizonte. Arquivo Público Mineiro. (APM) Secretaria de Governo. Seção Colonial (SC). Códice 04, f.695. Carta do Governador dom Pedro de Almeida e Portugal ao Rei dom João V, 22 de Agosto de 1719. (Grifo nosso).

6 Lisboa. Arquivo Histórico Ultramarino (AHU). Manuscritos Avulsos de Minas Gerais (MAMG). Caixa 36, doc.70. (Grifo nosso). 
governador Antônio de Albuquerque, na qual ordena a expulsão dos clérigos desnecessários, além de sugerir prudência para tratar com os mineiros, persuadindo-os a abstraírem-se dos delitos que cometiam e a "viverem como católicos, obedecendo as minhas ordens". Nas letras coloniais o bom vassalo é católico e obediente, portanto, não comete crimes. ${ }^{7}$

Todavia, se a religião esteve no rol das preocupações diárias das autoridades mineiras do século do ouro, a sua organização não foi regida pelas ordens regulares, tão comuns no litoral. Isso, em grande monta, para ataIhar os desvios de ouro e diamantes feitos pelos frades, mas também para "evitar as despesas da manutenção de convertidos e de mosteiros para o clero regular numa região em que [a Coroa] estava igualmente decidida a extrair a última onça de ouro em dízimos". ${ }^{8}$

A ausência das ordens primeiras (de frades e monges) e segundas (de freiras) tornou-se uma das características mais marcantes da vida religiosa nas Gerais, e que a distingue de outras localidades da América portuguesa. Nessa capitania, a religião nasceu órfã; foram os fiéis, unidos em confrarias, que se incumbiram da construção, manutenção e reedificação dos templos, pela contratação dos clérigos para celebrarem missas, enfim, pela organização do múnus religioso, num processo que se consolidou com a fundação do Bispado de Mariana, em 1745. ${ }^{9}$

Neste artigo, discute-se a organização da vida religiosa nas Minas, em sua fase de organização - que se estende de 1693, data oficial de sua ocupação, a 1745, ano de fundação do Bispado de Mariana -, relacionando o processo de implantação do catolicismo às preocupações políticas da coroa, expressas em documentos como os acima destacados. Além disso, mostra-se instigante perceber como as tensões e os conflitos sociais manifestos no cotidiano colonial mineiro interferiram no processo de construção do poder. Assim, através das relações norma/conflito, domínio/ apropriação, controle/resistências se articulam e se constroem os discursos religiosos e políticos, elementos importantes para se compreender aquele meio social.

Posta a relevância do catolicismo para a administração régia, a primeira pergunta a sobressaltar é: de que forma a religião - instância de intermediação entre o fiel e o sagrado - estabelecia relações com o político, domínio da construção da ordem e do poder social? ${ }^{10}$ Para responder a essa indagação, torna-se necessário compreendê-la em seu momento histórico

7 Carta de Lisboa de 09 de novembro de 1709. Apud: Revista do Arquivo Público Mineiro (RAPM), Belo Horizonte, v.XI, p.685-686, 1907.

8 BOXER, Charles R. O império colonial português (1415-1825). Lisboa: Edições 70, 1981, p.276.

9 A referência obrigatória para a análise da religião nas Minas é BOSCHI, Caio César. Os leigos e o poder: irmandades leigas e política colonizadora em Minas Gerais. São Paulo: Ática, 1986.

10 COUTROT, Aline. Religião e política. In: RÉMOND, René. (org.) Por uma história política. Rio de Janeiro: Ed. UFRJ, 1996, p.334. 
específico, buscando as suas amarras e conexões internas para, assim, ampliar o entendimento do político e do religioso.

\section{O padroado régio e a construção do poder}

No fim do Renascimento e início do período Moderno, a Igreja Católica tornou-se, em Portugal, dependente da Coroa. Por meio da concessão de uma série de direitos e deveres, transferidos pelo papado aos monarcas lusos, confirmados em bulas e breves pontificais, como a bula Inter Coetera, do Papa Calisto III (1456), Praecelsae Devotionis, de 1514 e, finalmente, por ratificação do Papa Julio III, na bula Praeclara Carissimi (1551), o rei foi proclamado grão-mestre da Ordem de Cristo - congênere mais rica, atuante e prestigiosa das ordens militares que combatiam nas Cruzadas. ${ }^{11}$ Por meio do Padroado Régio, e após a coroação dos príncipes lusitanos, estes se tornaram os patronos das missões e instituições eclesiásticas católicas em África, Ásia e América portuguesas, ${ }^{12}$ firmando-se, dessa forma, como os responsáveis pela conversão espiritual desses povos. Além disso, eles decidiam sobre a criação de dioceses e ereção de templos; indicavam os candidatos aos bispados; cobravam o dízimo, que era um dos principais tributos na época; ${ }^{13}$ aprovavam os párocos e sacerdotes para as paróquias e freguesias. Deveriam, ainda, cuidar do bom funcionamento da administração religiosa, remunerando os vigários através da côngrua régia; consentindo (ou vetando) os pedidos para edificação, reforma e ampliação de igrejas e capelas; aprovando os regimentos das irmandades e fiscalizando as festas. Praticamente tudo o que dizia respeito à religião dependia do crivo régio, exercido, por sua vez, pela Mesa de Consciência e Ordens - departamento da administração portuguesa que zelava pelos assuntos de consciência e fé. ${ }^{14}$

A política de dom João $V$ perpassou a sociedade em diversos níveis, dentre eles a religião. Essa associação não se deu somente pela devoção extremada do monarca, uma vez que, através da co-participação nos rituais salvíficos praticados por seus vassalos, procurou-se ordenar e controlar aquela sociedade, construindo o poder régio através do imaginário reli-

11 AZEVEDO, Thales de. Igreja e estado em tensão e crise: a conquista espiritual e o padroado na Bahia. São Paulo: Ática, 1978, p.23.

12 BOXER, Charles R. O império colonial português (1415-1825), p.257-258, 276.

13 GODINHO, Vitorino Magalhães. A estrutura na antiga sociedade portuguesa. Lisboa: Arcádia, 1971, p.89.

14 BOXER, Charles R. O império colonial português (1415-1825), p.257-258. Sobre o padroado régio, conferir ainda HOLANDA, Sérgio Buarque de. Raízes do Brasil. Rio de Janeiro: José Olympio, 1981, p.84-85; PRADO JÚNIOR, Caio. Formação do Brasil contemporâneo: Colônia. São Paulo: Brasiliense, 1977, p.321-333; DORNAS FILHO, João. O padroado e a Igreja brasileira. São Paulo: Companhia Editora Nacional, 1938; SERRÃO, Joel e OLIVEIRA MARQUES, A. H. (dir.) Nova história da expansão portuguesa: o Império luso-brasileiro (1620-1750). Lisboa, Editorial Estampa, 1991, v.VII, p.177-181. 
gioso..$^{15}$ Se esse aspecto se fazia presente em diversos momentos da vida social, podendo influenciar os fiéis, tornava-se importante manter o seu domínio com vistas a assegurar a governabilidade. Como brilhantemente aludiu Caio Prado Júnior, a monarquia portuguesa nunca se eximiu desse controle. ${ }^{16}$

Sabe-se que as mensagens religiosas somente poderiam ser disseminadas através de expressões culturais próprias a cada época. ${ }^{17}$ Destarte, a igreja também propagava o modus vivendi da civilização portuguesa, suas visões de mundo, modelos de administração, ética e moral. Destacam-se como veículos de divulgação religiosa (e política) os sermões e as homilias. ${ }^{18}$ Em época na qual a sociedade vivia, em sua maioria, apartada do domínio das letras, a cultura oral tinha um papel destacado na divulgação de mensagens políticas. ${ }^{19}$

Se, a partir do padroado régio, o catolicismo em Portugal jazia sob a tutela real, seria impensável que essa instituição questionasse os conceitos que sustentavam a monarquia, como a hierarquização social e o poder divino do rei. Para a divulgação de valores culturais e políticos convenientes aos "donos do poder", a condição essencial seria a vigilância dos responsáveis pela direção da igreja, dos bispos aos párocos, capelães e missionários. Por meio da interpretação dos textos canônicos e da ascendência moral sobre a população, os "funcionários" dessa "empresa de economia da salvação"20 divulgavam não somente o conteúdo doutrinal do catolicismo militante, mas também valores sociais. Como zeladores da vida religiosa e responsáveis pela vigilância da moral cristã, os eclesiásticos poderiam fazer crer em uma ordem natural, que deveria ser obedecida por todos. ${ }^{21}$

Outra coluna mestra que sustentou o catolicismo, para além da preservação da ordem natural e da hierarquia, mas que se relaciona intimamente com a mesma, foi o matrimônio religioso, que sedimentou e preservou um padrão para os relacionamentos afetivos. Com base no modelo da família monogâmica difundido pela igreja, conceitos como virtude e honra, e os padrões da moralidade cristã nela introduzidos reproduziam a obediência dos filhos aos pais, das mulheres aos esposos, dos súditos ao rei - um

15 Essa análise é aprofundada em DIAS, Renato da Silva. Para glória de Deus, e do Rei? Política, religião e escravidão nas Minas do Ouro (1693-1745). Belo Horizonte: UFMG, 2004 (História, Tese de doutorado).

16 PRADO JÚNIOR, Caio. Formação do Brasil contemporâneo, p.329.

17 COUTROT, Aline. Religião e política, p.334.

18 No período moderno, era bastante comum a presença dos predicadores que proferiam sermões, geralmente na Páscoa e, sobretudo, na Quaresma, mas também em outras épocas do ano litúrgico, como nas festas dos santos patronos. Sobre o tema, conferir: MORÁN, Manuel e GALLEGO, José Andrés. El predicador. In: VILLARI, Rosário. (coord.) El hombre barroco. Madrid: Alianza Editorial, 1992.

19 BOSI, Alfredo. Dialética da colonização. São Paulo: Companhia das Letras, 1992, p.25.

20 Segundo Max Weber, os padres são, distintamente dos profetas ou feiticeiros, "funcionários de uma empresa de economia da salvação", ou seja, administradores de uma instituição que promete a salvação no pós-vida, e não se propõe resolver problemas imediatos, como curar doentes, espantar espíritos - como fazem os feiticeiros - ou anunciar a "boa nova", como os profetas. WEBER, Max. Economia e sociedade, p.294.

21 COUTROT, Aline. Religião e política, p.337. 
arquétipo que se repetia, tornando o padrão hierárquico e a obediência virtudes naturais, e, por isso, inquestionáveis. ${ }^{22}$ Se, para o governador André de Melo e Castro, a igreja formava o melhor vassalo, para a monarquia, o casamento estabilizava, pois os homens tomavam maior "amor a terra". ${ }^{2} 3$

Nas Minas do Ouro, era urgente garantir o domínio da Coroa, o que significava divulgar modelos de comportamento social ajustados para assegurar a reprodução da auto-imagem cultivada pelo rei, como pai, bondoso e caridoso, além de manter o controle da violência social. Sabese que, embora o poder dinástico seja antigo em Portugal, primeiro estado a centralizar-se na Europa, diante das distâncias, ele precisava ser legitimado e tornar-se consensual na América portuguesa, ou seja, carecia ser construído socialmente. Deve-se, então, perscrutar o político não somente em seu registro mais aparente, em que é tradicionalmente procurado, mas também nas causas mais profundas, para, assim, se construir "uma história que inclua notadamente o simbólico e o imaginário". ${ }^{24}$ Além disso, diante da complexidade do "real", é preciso verificar as suas mediações, seus limites e o coeficiente de dependência/independência entre essa instância e o religioso nos diversos planos de penetração do poder.

\section{A reta e a elipse}

Muito embora a religião possa ser traduzida em recursos de poder, devese considerar que os sujeitos se ressentem em submeter-se passivamente a qualquer forma de coação, arbitrária ou sutil, pois não somente sofrem as influências do meio social, da cultura, da religião, das estruturas de poder, como também são agentes de transformação de sua própria história. No caso específico dos africanos traficados para a América portuguesa, não se pode supor, como se procurou demonstrar em outro trabalho,,$^{25}$ que o batismo e a doutrinação os tornavam passivos e obedientes. Pelo contrário, o que se observa é que os escravos e libertos refaziam suas vidas dentro das possibilidades viáveis da sociedade escravista colonial, procurando alargar direitos, esquadrinhando, nas frestas do sistema, novos espaços de negociação, marcando, através da resistência, ou mesmo da violência, os limites da própria ação dos senhores. ${ }^{26}$ Portanto, a análise do político via a questão religiosa demanda reflexão e esforço maior para entender os

22 COUTROT, Aline. Religião e política, p.334.

23 Ordem Régia. Lisboa, 22 de março de 1721. Apud: RAPM, v.30, p.124, 1979.

24 RÉMOND, René. Uma história presente. In: Por uma história política. Rio de Janeiro: Editora UFRJ, 1996, p.1415.

25 DIAS, Renato da Silva. Na África eu nasci, no Brasil eu me criei: a evangelização dos escravos nas Minas do Ouro. In: PAIVA, Eduardo França e IVO, Isnara Pereira. (orgs.) Escravidão, mestiçagem e histórias comparadas. São Paulo/Belo Horizonte/Vitória da Conquista: Annablume/PPGH-UFMG/Edunesb, 2008, p.293-311.

26 REIS, João José e SILVA, Eduardo. Negociação e conflito: a resistência negra no Brasil escravista. São Paulo: Companhia das Letras, 1989. 
homens em seu próprio tempo, como agentes sociais ativos, embora muitas vezes atuando sob circunstâncias extremamente adversas.

A eficácia da religião como mecanismo de controle social dependia de uma série de fatores. Em primeiro plano, destaca-se o período de enraizamento da própria sociedade em que se inscreve. O discurso religioso sofrerá reveses em sua implantação e estabilização em uma comunidade multicultural e de formação recente, como foi o caso das Minas setecentistas. Nessas plagas, a crença foi se estruturando aos poucos, e, na verdade, grande parte de seus moradores (tais como africanos, indígenas, mestiços e cristãos-novos) não se sentiam coibidos pelos preceitos da doutrina católica, permitindo a tomada de comportamentos desviantes, nem sempre tolerados em comunidades mais estabelecidas. Assim, dados como a carência de mulheres brancas para o casamento, a atração exercida pelas negras ${ }^{27}$ e as limitações sociais que recaíam sobre aqueles que contraíam núpcias com indivíduos de "raças infectas"28 somaram-se para aumentar a incidência de relações ilícitas, como o concubinato.

Esses fatores demográficos concorreram para agravar a instabilidade social nas Minas, pois, entre os primeiros povoadores, havia grande desequilíbrio na proporção sexual, pendendo o fiel da balança para os homens - grande maioria. De tal modo, muitos permaneciam solteirões, o que, acreditava-se, aumentava os índices de violência. A proibição da saída de mulheres brancas para o reino deve ser compreendida, portanto, como meio de promover as núpcias entre a camada branca, fato que controlaria aquela sociedade, evitando-se também a formação de elite mestiça.

Essa medida foi adotada por dom Pedro Miguel de Almeida Portugal que, em carta de 1721, informou ao soberano as dificuldades de se administrar a região, uma vez que, nas Minas, os povos não estavam "suficientemente civilizados e estabelecidos em formas de repúblicas regulares", e por isso rompiam facilmente em "alterações e desobediências", tornando-se necessário aplicar todos os meios para o seu controle. Nesse sentido, o monarca encarregou ao governador uma série de medidas para que "as pessoas principais e ainda quaisquer outras tomem o estado de casados e se estabeleçam com suas famílias reguladas na parte que elegerem para a sua povoação". Essa ação se justificou na medida em que, casados e com filhos para criar, esses povoadores teriam "mais amor à terra e maior conveniência ao sossego dela e consequentemente ficarão mais obedientes às minhas reais ordens e os filhos que tiverem do matrimônio os

27 Foi Gilberto Freyre que, em sua obra clássica, apontou para o aspecto mítico que as negras ("mouras encantadas") assumiram no imaginário português, aspecto encontrado nas Minas, onde os mineradores acreditavam que só teriam sorte na mineração se houvessem consigo uma negra Mina. FREYRE, Gilberto. Casa grande \& senzala: formação da família brasileira sob o regime da economia patriarcal. Rio de Janeiro: José Olympio, 1969.

28 BOXER, Charles Ralph. Pureza de sangue e raças infectas. In: O império marítimo português (1415-1825), p.262286. 
façam ainda mais obedientes". Nessa ordem, há também uma solicitação de parecer em que se indaga se seria conveniente que somente os casados pudessem ser eleitos para os cargos da vereança, e, nesse caso, se haveria número suficiente dos mesmos para que se pudesse praticá-la. ${ }^{29}$ A interdição da participação nos cargos públicos aos solteiros tornou-se uma forma de obrigar as elites e as camadas brancas médias - desejosas de participarem de uma instituição que propiciaria prestígio social - a tomarem os contratos esponsalícios. Em resposta à petição, a administração de dom Lourenço de Almeida se notabilizou pelas medidas adotadas para a pacificação da região. Em carta de vinte e oito de setembro do mesmo ano, esse governador respondeu à consulta régia e afiançou que "nestas Minas não havia mulheres brancas que houvessem de casar". ${ }^{30}$ Assim, a solução do impasse seria introduzir a maior quantidade possível de casais, visto que, naquela região, todos os moradores "são moços e solteiros e por esta causa menos obedientes", pois,

como não tem [o] que perder por ser o seu cabedal pouco volumoso por consistir todo em ouro, nem mulher e filhos que deixar, não só se atrevem a faltar à obediência e às justiças de Vossa Majestade, senão também a cometerem continuamente os mais atrozes delitos como estão sucedendo nestas Minas, ainda que hoje com mais alguma moderação. ${ }^{31}$

Percebe-se claramente, nesse discurso, a crença no casamento como pacificador social, o que tornaria os homens mais obedientes ao mando régio. Para dom Lourenço, se a maioria dos habitantes da capitania fosse composta por casados, evitar-se-iam tais atropelos, uma vez que esses sempre vivem com mais sossego: "atendendo à conservação de sua família e da terra aonde a querem perpetuar, e não só dão exemplos aos mais, senão também de algum modo os obrigam a proceder bem". Nessa verdadeira análise sociológica, o governador percebeu não apenas que os homens casados eram menos propensos a cometer atos violentos, como também seriam mais zelosos em suas atividades, rendendo, assim, maior lucro ao erário régio. Observou-se, também, que eles poderiam convencer os solteiros a abandonar seu comportamento irascível; por isso, as uniões in faccie eclesiae funcionariam como reguladoras sociais.

Para aumentar o número de casais naquela região, dom Lourenço achou por bem "que nenhuma mulher do Brasil possa ir para Portugal nem Ilhas a serem freiras", pois acreditava que, sem esse veto, todas as mulheres tornar-se-iam monjas, ainda mais com a fundação de um novo convento

29 Ordem Régia. Lisboa, 22 de março de 1721. Apud: RAPM, Belo Horizonte, v.30, p.124, 1979. (Grifo nosso).

30 Carta de dom Lourenço de Almeida, Governador das Minas ao Rei, Vila Rica, 19 de abril de 1722. Apud: RAPM, Belo Horizonte, v.31, p.110, 1980

31 Carta de dom Lourenço de Almeida, Governador das Minas ao Rei, Vila Rica, 19 de abril de 1722. Apud: RAPM, Belo Horizonte, v.31, p.109-110, 1980. 
no Rio de Janeiro. Guiado por motivações extremamente utilitaristas, o mesmo concluiu que não seria justo "que [se] despovoe o Brasil por falta de mulheres". 32

Aos vinte de abril de 1722, as decisões tomadas pelo governador tornaram-se ainda mais radicais e inusitadas, pois, diante da "má qualidade de gente" que vai enchendo as Minas, e da inexistência de outras "castas" de mulheres senão as negras, a proporção dos mulatos aumentou. Nesse caso, o problema é que, em decorrência do concubinato com as africanas, estes herdariam os bens de seus pais, enriquecidos pela extração do ouro, e, em poucos anos, possuiriam cabedais, tornando-se perigosos, principalmente diante da "distância e largueza" da região, dificultando a sua dominação. Então, "para se evitar a ruína", dom Lourenço de Almeida sugeriu que, "das terras da marinha deste Brasil ou das Ilhas, onde há muita quantidade de casais pobríssimos", fossem enviadas todas as famílias possíveis às Minas, e aconselhou ao rei que, se fosse lícito, promulgasse alguma lei contra o direito natural, para impedir que "nenhum mulato possa ser herdeiro de seu pai ainda que não tenha outro filho branco". Nesse caso, os parentes mais próximos herdariam os bens, fato que os deixaria mais "abatidos". Assim, o governador acreditou que muitos dos brancos iriam se abster de gerar "semelhantes filhos", isto para não "experimentar-se a ignomínia de não poderem ser herdeiros seus". ${ }^{33}$ Essa tentativa desesperada para impedir a mulatização da capitania refletiu-se, posteriormente, na política régia.

Quatro anos após as considerações feitas por dom Lourenço de Almeida para o melhor estabelecimento das Minas, a Coroa interditou os cargos de vereador, juiz ordinário e outras funções de comando das vilas à participação de "homem algum que seja mulato, dentro nos quatro graus em que o mulatismo é impedimento e que da mesma sorte não possa ser eleito o que não for casado com mulher branca ou viúvo dela". Dessa sorte, aqueles ofícios ficariam "dignamente ocupados" e, assim

poderá conseguir-se que os homens deste País procurem deixar descendentes não defeituosos e impuros, vendo que de outro modo não podem alcançar nem para si nem para os seus o emprego de maior distinção e honra das terras em que vivem pois o fato de consegui-los é natural a quase todos os homens. ${ }^{34}$

Como se pode perceber, as ordens dadas para normatizar o casamento nas Minas do Ouro se relacionavam ao controle da violência, mas demonstram também os preconceitos raciais em voga naquele período. Já em 1731, o então governador André de Melo e Castro, retomando a argumentação

32 RAPM, v.31, 1980, p.110. Carta de dom Lourenço de Almeida, Governador das Minas ao Rei. Vila Rica, 19 de abril de 1722

33 RAPM, v.30, 1979, p.12-13. Carta de dom Lourenço ao Rei. Vila Rica, 20 de abril de 1722.

34 APM. SC.29. Ordem Régia. Lisboa, 27 de janeiro de 1726, f.17. (Grifo nosso). 
dada nove anos antes, por dom Lourenço, reiterou o pedido ao rei para proibir que qualquer mulher das Minas, e de "todo o estado do Brasil", pudesse ir a Portugal para se tornar freira, uma vez que estas se deslocavam ao reino contra a sua vontade. Para o conde das Galvêas, "como se acham os cabeças de famílias com dinheiro para dotes de suas filhas, não cuidam em outra coisa senão em mandá-las para freiras", prática comum às gentes "de baixo nascimento". ${ }^{35}$ No ano seguinte, em ordem dirigida a André de Melo e Castro, dom João V proibiu "que de todo esse Estado do Brasil não venha mulher para este Reino sem licença minha". Essa ordem foi publicada incontinenti nas Minas. ${ }^{36}$

\section{Frades e vigários: intermediários de poder?}

Segundo a doutrina católica, os párocos devem sempre vigiar as suas ovelhas, emendando seus erros, dando exemplos morais nos sermões, aconselhando-as nas confissões e, nos casos mais graves, como pais espirituais, punindo os desviantes. ${ }^{37}$ Sem embargo, as tentações do dinheiro e da carne, a falta de vigilância dos superiores e a carência de vocação na carreira eclesiástica facilitavam as condutas irregulares dos sacerdotes. Para impedir os abusos pessoais, o descumprimento das obrigações, e atendendo as reclamações sobre os maus hábitos dos curas d'alma, os governadores estavam sempre a informar as irregularidades cometidas pelos padres, nas Minas, ao bispo ou ao monarca. Por meio de ordens régias, dirigidas às autoridades coloniais, a Coroa intentava normalizar a vida religiosa, ordenando a prisão e/ou expulsão do clero desordeiro.

Em seu sentido político, a Igreja procurava conter a violência, organizar o corpus social, fazer reconhecer a autoridade régia e as distinções entre o povo comum e as pessoas de "mor qualidade". Contudo, não se pode deduzir que tais formas de controle fossem passivamente aceitas pela população, ou mesmo cumpridas pelos eclesiásticos. Sob esse ponto, crê-se que a história não pode ser constrangida pelas teorias, posto que os sujeitos podem se rebelar segundo sua capacidade de articulação, transformando práticas culturais estabelecidas.

Estudos que analisam a conduta política do clero colonial frequentemente se posicionam a partir de dicotomias tais como controle/descontrole,

35 APM. SC.32. Carta do Conde das Galvêas ao Rei, 05 de junho de 1731, f.105

36 Conferir, respectivamente, APM. SC.36. Ordem Régia. Lisboa, 14 de abril de 1732, f.6v e APM. SC.36. Vila Rica, 06 de outubro de 1732, f.82v. A carta-resposta sobre a proibição da saída das mulheres do Brasil para o Reino é de outubro do mesmo ano.

37 "Porque aos Parochos, como Pastores, e Mestres espirituaes, obriga mais o cuidado de apascentar suas ovellhas com a Catholica, e verdadeira Doutrina (sic)". Constituições Primeiras do Arcebispado da Bahia. Feitas e ordenadas pelo llustríssimo, e Reverendíssimo Senhor dom Sebastião Monteiro da Vide, Arcebispo do dito Arcebispado, e do Conselho de Sua Majestade, propostas e aceitas em o Sínodo Diocesano, que o dito Senhor celebrou em 12 de Junho do ano de 1707. São Paulo: Tipografia de Antônio Louzada Antunes, 1853. (CPAB, Liv.l, tit.III, §6). 
submissão/independência, obediência/revolta, e a historiografia mineira não escapou a essa tendência. Vistos comumente como elementos responsáveis pelo ordenamento social, como funcionários régios, em diversas outras ocasiões, porém, o clero foi considerado desordeiro, corrompido e perturbador da paz. Tais afirmações, quando postas no lugar-comum das generalizações, tornam-se expressões estereotipadas, vazias, e sem viço para gerar novos frutos para a sebe histórica. Do mesmo modo, apesar de terem existido, nas Minas setecentistas, eclesiásticos que abraçaram atitudes condenáveis ao seu estado, não se pode concluir, no entanto, que todos os padres mineiros fossem viciosos e violentos; ou, por outro lado, que fossem fiéis escudeiros do rei! A generalização de atitudes individuais é um passo perigoso que pode conduzir à construção de teorias desconexas e, portanto, incapazes de dar sentido aos fatos históricos e sociais. ${ }^{38}$ Para além de apreciações polarizadas, deve-se manter o esforço para perceber as tensões - que se revelam extremamente ricas - produzidas no interior daquela sociedade, bem como procurar aproximar-se dos sujeitos sociais, num empenho para apreender as diversas variáveis que concorrem para definir as maneiras de ver, sentir e reagir dos indivíduos. ${ }^{39}$

Grosso modo, Max Weber define os sacerdotes (em oposição aos feiticeiros e profetas) como funcionários de uma empresa permanente de "economia da salvação", regulada e organizada com o objetivo de influenciar os deuses. Representam ainda as normas sagradas da comunidade religiosa e estabelecem, regulam e prescrevem as cláusulas do culto, delimitando o que é ou não sagrado. Exercendo atividade de ligação com o mundo dos deuses, os sacerdotes desempenhavam, por sua ascendência moral sobre os leigos, um forte papel social de respeito e de liderança. ${ }^{40}$ Isso foi o que se viu também em diversos e conturbados momentos da história das Minas.

Quase imediatamente à ocupação do território mineiro, seus habitantes presenciaram, assombrados, ao conflito conhecido por Guerra dos Emboabas. Iniciada pelas rivalidades entre os colonizadores paulistas, que viam o controle da região mineradora passar de suas mãos para as dos moradores de outras capitanias e dos portugueses (emboabas), que aspiravam determinar as repartições de sesmarias e, conseqüentemente, o mando da região, essa rebelião movimentou centenas de homens, e abalou a governabilidade

38 Segundo Max Weber, não se pode deduzir o "sentido" dos acontecimentos mundiais como resultado de um estudo, posto que somos nós que o construímos, e essa construção é resultado de escolhas, e não somente da acumulação empírica de dados. WEBER, Max. Sobre a teoria das Ciências Sociais. Lisboa: Editorial Presença, p.21-22.

39 Essa discussão foi desenvolvida em: DIAS, Renato da Silva. Aos pés do altar e do Rei? O clero nas Minas setecentistas e a historiografia. In: Anais do IV Simpósio Internacional de Estudos sobre América Colonial/CASO. Belo Horizonte: UFMG, 2008. (CD-ROM).

40 WEBER, Max. Economia e sociedade, p.294. 
da região. ${ }^{41}$ Presentes nesses momentos, e representando tanto a facção liderada por Manoel Nunes Vianna, que comandava os emboabas, quanto a de Amador Bueno, chefe dos paulistas, estavam os sacerdotes, que atuaram no conflito como mediadores de poder, e mesmo como líderes. ${ }^{42} \mathrm{Em}$ diversos momentos, quando a ordem social sofreu abalos, os eclesiásticos se fizeram presentes, auxiliando os governantes ou, por outro lado, insuflando a população para praticar atos violentos sob pena de excomunhão, apontando pessoas do púlpito e liderando grupos armados.

Exemplo disso pode ser depreendido da carta régia de outubro de 1710, quando Antônio de Albuquerque foi informado para não admitir, naquela capitania, o frei Francisco de Meneses, mesmo se este apresentasse permissão régia. O motivo que induziu essa atitude foi o fato de esse cura ter-se tornado "um dos principais cabeças do levantamento das Minas contra os paulistas". No ano seguinte, dom João V ordenou ao governador que o informasse sobre o procedimento do padre Cláudio Gurgel do Amaral, nomeado, pelo bispo, vigário de Ouro Preto, e declarou que "sua assistência na terra será danosíssima", uma vez que o clérigo foi, no Rio de Janeiro, "autor de algumas revoluções em que sucederam mortes". ${ }^{43}$ Muitos desses religiosos saíam de regiões distantes, como da Bahia, Rio de Janeiro ou Maranhão, e se dirigiam às Minas, no afã do enriquecimento fácil. Outros vinham de mais longe ainda, como Portugal, Itália, Goa ou mesmo de Macau, para arrecadar fundos para obras pias, recolher benefícios para a Bula da Santa Cruzada ou para "os lugares santos de Jerusalém", mas nem todos visavam a obras beneméritas. ${ }^{44}$

Além dos sacerdotes citados acima, muitos eram os que desafiavam o poder e a autoridade, a exemplo de Antônio de Curvelo d'Ávila, vigário de Nossa Senhora do Bom Sucesso, que pregava pastorais contra a ordem e chegou a levantar toda a população que o acompanhava, sob pena de excomunhão, para matar um emissário do governador. ${ }^{45}$ Havia ainda o vigário Joseph Simões, que, não aceitando o pagamento para dirigir a procissão nas ladainhas de maio, reuniu-se com os demais clérigos para chegar somente ao meio-dia, deixando os oficiais da câmara aguardando na igreja, e, além disso, aproveitou a ocasião e "descompôs injuriosamente a todo o

41 VASCONCELOS, Diogo de. História antiga das Minas Gerais. Belo Horizonte: Itatiaia, 1974.

42 Conferir a "História do distrito do Rio das Mortes, sua descrição, descobrimento das suas minas, casos nele acontecidos entre paulistas e emboabas e ereção das suas vilas" e "Dou parte do que vi e sei". Apud: FIGUEIREDO, Luciano Raposo de A. e CAMPOS, Maria Verônica. (orgs.) Códice Costa Matoso. Coleção das notícias dos primeiros descobrimentos das minas na América que fez o doutor Caetano da Costa Matoso sendo ouvidorgeral do Ouro Preto, de que tomou posse em fevereiro de 1749, \& vários papéis. Belo Horizonte: Fundação João Pinheiro, Centro de Estudos Históricos e Culturais, 1999, p.227-242; 210-216.

43 APM. SC.03. Cartas Régias. Lisboa, 12 de outubro de 1710 e 26 de março de 1711, f.49v.

44 Os desvios dos religiosos chegaram a tal ponto que muitos clérigos abandonaram suas missões, como fizeram os religiosos do Maranhão, e se dirigiram às Minas. Esses pertenciam a várias ordens: eram carmelitas, franciscanos, jesuítas.

45 APM. SC.04. Carta Régia. Lisboa, 12 de janeiro de 1720, f.283-286. 
Senado". Por mais de uma vez, destratou, inclusive em sua residência, na presença de várias pessoas, o procurador da câmara de Vila do Carmo, Manoel de Vargas Queiroga. Além do mais, o pároco protegia devedores da lei em sua casa, aproveitando, para isso, das isenções eclesiásticas. Certamente, esse era um comportamento "alheio ao estado eclesiástico ofensivo da jurisdição real e muito injusto para os Ministros que a Vossa Majestade serve[m] com honra e desinteresse". ${ }^{46}$

\section{Igrejas e bispado, ou a cruz e a espada}

Para regular o clero mineiro e dirimir os problemas causados pelo abuso de poder por parte de muitos sacerdotes foi considerada a melhor solução torná-los "colados". ${ }^{77}$ Mas, nas Minas, era assaz baixo o número de vigarias colativas. A justificativa para esse coeficiente reduzido estava no fato de o Conselho Ultramarino não querer vigários perpétuos, pois se acreditava que as Minas não seriam duráveis - o que talvez se explique pelo fato de a exploração aurífera ser primordialmente de aluvião, ou realizada nas grupiaras e em minas pouco profundas, o que provocava rápida exaustão desse recurso. Sendo assim, não haveria "ovelhas para tantos pastores". Como resultado, a prática religiosa foi deixada para plano secundário. Para Assumar, não haveria prejuízo algum tornar os párocos fixos, recebendo a côngrua régia, ${ }^{48}$ pois, se acaso os fiéis evadissem para outras regiões, os mesmos seriam transferidos. Para ele, o pior dos males no "estado eclesiástico" provinha das carências vividas pelos vigários sem pagamento, pois dessa forma, eles acabavam por abandonar seus paroquianos e abusavam das taxas no intuito de enriquecer em um ou dois anos. ${ }^{49}$

Eram altos os valores cobrados por conhecenças, ${ }^{50}$ por isso, o governador sugeriu ao bispo dois remédios: "ou colá-los Sua Majestade para perpétuos, ou perpetuá-los Vossa llustríssima, quando não fosse colá-los, concedendo-lhes as provisões por mais anos", pois assim lograrão o be-

46 APM.SC.36. Carta de Manoel Caetano Gaspar ao Rei. Vila do Carmo, 1733, f.53.

47 Segundo o Glossário do Códice Costa Matoso o vigário colado era o sacerdote provido pelo rei após ser sabatinado pelo bispo para ser provido perpetuamente para uma vigararia, à qual se tornava inamovível (ficava "colado"). O benefício implicava o direito de receber o pagamento régio (côngrua). FIGUEIREDO, Luciano Raposo de A. e CAMPOS, Maria Verônica. (orgs.) Códice Costa Matoso, v.2, p.127.

48 A côngrua era a "Remuneração anual paga pela Coroa ao clero secular com cargos colados (confirmados), para seu sustento, em virtude do regime de padroado, pelo qual a Coroa recolhe em seu favor os dízimos eclesiásticos e, em troca, arca com as despesas com os sacerdotes e o culto divino". FIGUEIREDO, Luciano Raposo A. e CAMPOS, Maria Verônica. (orgs.) Códice Costa Matoso, v.2, p.87.

49 APM. SC.11. Carta de Assumar ao bispo do Rio de Janeiro. Vila do Carmo, 13 de setembro de 1718, f.50, v.53. A "côngrua" régia equivalia, na época, a duzentos mil réis.

50 As conhecenças eram o dízimo pessoal pago pelo fiel a seu pároco pelo serviço pastoral. Ele incide sob sobre todos os seus ganhos "em função de qualquer negócio, serviço ou ofício, mesmo fora da respectiva paróquia, por ocasião da desobriga pascal. Destinadas formalmente ao sustento dos párocos encomendados, que não têm direito às côngruas, na prática também os párocos colados recebem as conhecenças". A "desobriga pascal" era o cumprimento do preceito segundo o qual todo o cristão deve confessar-se e comungar ao menos uma vez ao ano, geralmente na ocasião da Quaresma. FIGUEIREDO, Luciano Raposo A. e CAMPOS, Maria Verônica. (orgs.) Códice Costa Matoso, v.2, p.87 e 91. 
nefício que recebem por tempo limitado. E isso era necessário, pois alguns padres pretendiam forçar seus fregueses através da justiça secular a pagarIhes os valores exorbitantes e, além disso, davam exemplos "impróprios ao seu estado", uma vez que "a instituição de um prelado é ser mediador entre Deus e os Homens, e oferecer-Ihe sacrifícios pelos pecados de todos". ${ }^{51}$

Aspecto que prejudicava enormemente a ação pastoral, a carência de verbas para a Igreja foi o resultado direto da lógica e dinâmica do antigo sistema colonial, ${ }^{52}$ uma vez que o interesse maior da Coroa consistia na tributação e no fiscalismo. Desse modo, os governadores contabilizavam as receitas e despesas nas regiões das Minas, e, através desses cálculos, o rei julgava as necessidades da vida espiritual. Assim, quanto maior o número de paróquias, maiores os gastos para a manutenção dos vigários colados e para a "decência do culto de Deus". A criação de capelas e a colação dos párocos tornava-se uma das formas de aumentar o controle sobre os eclesiásticos, bem como da própria população, mas as necessidades espirituais também dependiam do equilíbrio da balança orçamentária. Segundo o que informou dom Pedro de Almeida, em 1718, havia cinquenta paróquias, mas, diante do número considerado reduzido de fregueses, e do custo para a Fazenda real, o bispo do Rio de Janeiro pretendia unir algumas delas. ${ }^{53}$

No ano seguinte, Assumar já havia recebido a resposta do bispo para determinar o valor das conhecenças, fixadas, então, em seis oitavas de ouro. Quanto ao número exorbitante das capelas, esse governador foi informado pelo presbítero que deveria anexar aquelas menores às maiores, assunto com o qual se sentia embaraçado, por não se saber "com certeza quais são os vigários a que se deve pagar a côngrua (sic)". No final da segunda década do setecentos a administração eclesiástica ainda sofria com as falhas da burocracia e com as distâncias, pois era o governador quem se esforçava para resolver os problemas relativos ao múnus religioso, mesmo não sendo o mais qualificado para isso. O conde de Assumar ainda insistia na necessidade de tornar os vigários "colados", pois, assim, seriam "proveitosos" para a "boa administração dos povos e bom exemplo, como também para a sua quietação e para o serviço de Deus". Nesses documentos, dom Pedro de Almeida declara a finalidade da normalização

51 APM. SC.11. Carta de Assumar ao bispo do Rio de Janeiro. Vila do Carmo, 13 de setembro de 1718, f.50, v.53.

52 O termo foi cunhado por Caio Prado Júnior e desenvolvido por Fernando Antônio Novais. Conferir, respectivamente: JÚNIOR, Caio Prado. Formação do Brasil contemporâneo, 1977; NOVAIS, Fernando Antônio. Portugal e Brasil na crise do Antigo Sistema Colonial (1777-1808). São Paulo: Hucitec, 1979.

53 APM. SC.11. Carta do governador dom Pedro de Almeida e Portugal, conde de Assumar, ao bispo do Rio de Janeiro. Vila do Carmo, 13 de setembro de 1718, f.50, v.53. Se, em 1718, constavam cinqüenta paróquias nas Minas, no relatório ad limina, enviado ao Papa, dom Frei Manoel da Cruz, primeiro bispo marianense, afirmou, em 1757, que, nas Minas, havia 43 igrejas paroquiais maiores, com reitores colados, de três amovíveis, e 289 igrejas menores a elas filiadas. Não se sabe se os dados de Assumar eram exatos, mas presume-se que a ordem do bispo do Rio de Janeiro de reduzir o número de paróquias foi seguida. Relatório de dom Frei Manoel da Cruz à Santa Sé. Mariana, 01 de julho de 1757. Divulgação Monsenhor Flávio Carneiro Rodrigues. 
do clero, que deveria mediar as relações entre Deus e os homens, dando bom exemplo e quietando os povos!

Por fim, em 1721, após ter-se informado por pessoas mais experientes na matéria, dom Pedro de Almeida finalizou a relação das paróquias que ficariam nas Minas e daquelas que seriam reduzidas a capelas curadas: ${ }^{54}$

Quadro I: Paróquias e capelas curadas em Minas Gerais (1721)

\begin{tabular}{|l|l|}
\hline Vigarias [paróquias] que ficam: & Capelas que podem ser curadas: \\
\hline Ouro Preto & Antônio Dias / São Bartolomeu \\
\hline Cachoeira & A capela de Bar. de Godois \\
\hline Itaubira & Carijós / Congonhas / Itatiaia \\
\hline Ouro Branco & $\begin{array}{l}\text { S. Sebastião / Antônio Pereira / Sumi- } \\
\text { douro / Brumado }\end{array}$ \\
\hline Ribeirão do Carmo & \\
\hline & São Caetano \\
\hline Bom Jesus do Forquim & Noroega / Itaberava \\
\hline Guarapiranga & Inficcionado / Camargos e Bento Roiz \\
\hline Catas Altas & Santo Antônio no Rio de S. Barbosa \\
\hline & \\
\hline & Rossa Grande / Curral de El Rey \\
\hline Vila Real do Sabará & Raposos \\
\hline & Morro Vermelho / São Miguel \\
\hline Vila Nova da Rainha & Conceição do Rio do Peixe \\
\hline Vila do Serro do Frio & Rio da Onça \\
\hline Vila de Pitangui & Caminho Velho / Caminho Novo \\
\hline Vila de São João do Rio das Mortes & Prados / Lagoa Dourada \\
\hline Vila de São Joseph & \\
\hline
\end{tabular}

Segundo a disposição acima, percebe-se que as paróquias ficariam localizadas geograficamente no centro das capelas curadas, distantes daquelas em até duas léguas, numa divisão que obedeceu primordialmente a jurisdição secular, com exceção de Ouro Branco, que pertencia à comarca

54 FIGUEIREDO, Luciano Raposo A. e CAMPOS, Maria Verônica. (orgs.) Códice Costa Matoso, v.2, p.82 e 91. As capelas curadas eram aquelas que eram servidas por um cura, ou seja, por um sacerdote auxiliar do pároco, "com território desmembrado da paróquia e autonomia no exercício das funções pastorais". 
do Ouro Preto, e Congonhas e Carijós, vinculadas à comarca do Rio das Mortes, distintas das demais para maior comodidade do vigário. ${ }^{55}$

Até a fundação do Bispado de Mariana, em 1745, nas Minas, a vida religiosa carecia até mesmo do estritamente necessário, pois, além de muitos vigários não cumprirem suas obrigações religiosas a contento, nos primeiros anos de sua ocupação, não havia sequer uma Santa Casa de Misericórdia, instituição sumamente necessária, uma vez que o governo português nunca primou pela assistência social, ${ }^{56}$ e só esporadicamente missionários capuchinos, carmelitas, franciscanos ou jesuítas visitavam a região, trabalhando na cura das almas.

Em 1724, entendendo ser insuficiente o número de paróquias que Assumar e o bispo do Rio de Janeiro apontaram para serem "coladas", e percebendo que havia outras "que pelo sitio, rendimento e número de fregueses merecem igualmente ser eretas em vigairarias (sic)", o rei permitiu a criação de mais algumas vigarias, que desfrutariam dos mesmos benefícios das demais. Do mesmo modo, por decisão da Mesa de Consciência e Ordens, os párocos receberiam duzentos mil réis de côngrua, e os sacerdotes das igrejas que se tornaram curatos embolsariam a taxa de seis vinténs por conhecenças. Com o novo mapa dos templos alçados à qualidade de paróquias coladas, além das treze apontadas por Assumar e pelo bispo, ${ }^{57}$ acrescentaram-se mais seis, a saber: a igreja do Rio das Pedras, de São Sebastião, de Santa Bárbara, de São Bartolomeu, dos Raposos e a do Bom Retiro. Dessas, as de Antônio Dias, São Bartolomeu e Raposos constavam na lista de 1721, indicadas para capelas curadas, enquanto as outras não haviam sido assinaladas anteriormente. Os santuários de Cachoeira e Itabira, indicados na lista anterior, foram excluídos do novo rol, ficando, talvez, para capelas curadas. ${ }^{58}$ Somente 28 anos depois, em 1752, para atender aos "prejuízos espirituais e temporais" dos moradores de Itabira, que não tinham vigários próprios para que, "com amor e caridade pudessem cuidar no amor espiritual de suas almas", o rei permitiu que se erigisse a igreja da Boa Viagem de Itabira, com a côngrua de duzentos mil réis anualmente pagos àquele que fosse provido. ${ }^{59}$

55 APM. SC.13. Carta do governador dom Pedro de Almeida ao cabido da Sé vacante do Rio de Janeiro. Vila do Carmo, 02 de julho de 1721, fl.37, v.8. Na tabela, optou-se por manter a grafia original.

56 RUSSELL-WOOD, A. J. R. Fidalgos e filantropos: a Santa Casa da Misericórdia da Bahia, 1550-1755. Brasília: EdUNB, 1981; RUSSELL-WOOD, A. J. R. The black man in slavery and freedom in colonial Brazil. New York, 1982, p.120.

57 São elas: a igreja da Vila do Ribeirão do Carmo; da Vila de São João de El Rey; a igreja de Santo Antônio da Vila de S. José do Rio das Mortes; da Vila Nova da Rainha do Caethe; de Catas Altas; a igreja do Príncipe do Serro Frio; a igreja de N. Sra. da Piedade de Pitangui; a igreja de Guarapiranga; a igreja do Bom Jesus do Furquim; a igreja do Ouro Branco; a igreja de Vila Real do Sabará; a igreja de N. Sra. da Conceição do Sitio de Antônio Dias, e a igreja matriz de Vila Rica do Ouro Preto.

58 AHU. MAMG. Decreto de dom João V concedendo a ereção de outras igrejas nas Minas, 12 de fevereiro de 1724 Caixa 5, doc.09

59 APM. SC.93. Alvará Régio. Lisboa, 16 de janeiro de 1752, f.155v. 
A definição das vigarias e a instalação dos referidos párocos, fixos em regiões estrategicamente escolhidas, revelavam-se à Coroa como meio eficaz de organização social e, consequentemente, de subordinação dos fiéis/vassalos e dos próprios eclesiásticos desviantes. Apesar disso, novamente, a medida mostrou-se insuficiente, pois muitos clérigos sem emprego continuaram na região. O desaforo destes era tamanho: enquanto alguns andavam ministrando sacramentos sem licença, outros se eximiam de suas obrigações como pastores, atirando-se nos braços do comércio ou mesmo alugando escravos para a mineração. O número de padres revoltosos na região e a repetição ad nauseam das ordens para sua expulsão são indícios claros de que estas não eram obedecidas, ao mesmo tempo em que denota a dificuldade de ordenação social naquelas paragens.

Além da organização das paróquias e da determinação para que os prelados se dedicassem às suas atividades, percebeu-se, desde muito cedo, que a largueza das Minas tornava impossível ao bispo do Rio de Janeiro "acudir as obrigações de bom pastor de ovelhas", o que facilitava àqueles viverem soltamente. Dessa forma, no mesmo ano em que começou a fundar as primeiras vilas nas Minas, Antônio de Albuquerque enviou carta ao rei, instando a criação de um bispado para as regiões de São Paulo e Minas, separado da jurisdição do Rio de Janeiro. Em resposta à missiva, dom João $V$ ordenou ao governador que informasse quantas vilas e povoações havia na comarca da Serra para Cima - marco divisor do novo bispado - e quantas ficavam "abaixo da serra para o mar pertencente ao bispado do Rio de Janeiro", e ainda a distância deste a São Paulo. ${ }^{60}$

Na Sedição de Vila Rica, quando Manuel Mosqueira da Rosa, Paschoal da Silva Guimarães e Felipe dos Santos organizaram uma sublevação geral, também participaram, como insufladores do povo, alguns religiosos, como Francisco Vicente e Francisco de Monte Alverne. Agindo prontamente, dom Pedro de Almeida armou uma cilada para capturar os líderes da revolta, e documentos informam que Monte Alverne se escondeu provisoriamente na casa de Paschoal da Silva, seu patrão. ${ }^{61}$ Pelo que se pode perceber, esses sacerdotes eram protegidos dos potentados, mas o que se deve questionar era por que esses homens, poderosos da terra, sempre se ligavam aos clérigos? Os padres exerceriam alguma influência sobre a população? A resposta é claramente positiva. Três meses após a carta de Assumar, e para evitar a "grande dissolução e distraimentos nos eclesiásticos", foi ordenada, em 1720, a fundação de dois novos bispados: um em São Paulo e o outro nas Minas do Ouro. ${ }^{62}$

60 APM. SC.05. Carta Régia. Lisboa, 12 de março de 1712, f.27v. Percebe-se que a solicitação seguiu a divisão administrativa da capitania, que, três anos antes, havia sido separada da do Rio de Janeiro.

61 APM. SC.13. Carta do Conde Governador dom Pedro Miguel de Almeida Portugal. Vila do Carmo, 13 de julho de $1720, f 1.22$

62 APM.SC.03. Ordem Régia. Lisboa, 06 de setembro de 1720, f.51v. 
Apesar de indicada a criação do episcopado em 1720, somente em 1745 sua fundação se concretizou e, nesse intermezzo, muitos problemas trouxeram dores de cabeça aos governantes. A organização da vida religiosa atingiu seu ponto de equilíbrio com a instituição do bispado mineiro e, mais concretamente, após a acomodação, de fato, do primeiro presbítero a ocupar seu lídimo lugar no sólio de Mariana, dois anos após sua nomeação. ${ }^{63}$ Já instituído primeiro bispo das Minas, mas antes mesmo de se aventurar em extenuante viagem do Maranhão à Mariana, dom Manoel da Cruz solicitou ao rei a construção de um seminário, que se fazia muito preciso em sua diocese, "não só para a educação de seminaristas, mas também para nele haverem estudos públicos". Destaca-se que essa obra já havia sido iniciada, pois duas casas grandes foram compradas, com suas terras, "na melhor e mais agradável paragem daquela cidade", que com reformas poderia recolher uma grande comunidade de seminaristas. No mesmo edifício residiam um mestre da Companhia de Jesus do Rio de Janeiro e treze seminaristas, muitos dos quais aptos a cursar filosofia. Carecia-se, todavia, de mais três lentes para lecionarem teologia moral e outro para prefeito dos estudos da Companhia. Também nessa carta, dom Manuel da Cruz requisitava ao provincial da Bahia que enviasse mais quatro mestres idôneos para o seminário, para praticar os exercícios espirituais de Santo Inácio e fazer missão, ajudando a bem morrer. A criação do seminário da Nossa Senhora da Boa Morte foi esperada com grande alvoroço. ${ }^{64}$

\section{A arte de viver: apropriação cultural}

A formação multicultural das Minas inseriu novos dados e dificuldades para a tentativa de controle social através da religião. Nessa capitania, a população não se constituiu exclusivamente de portugueses, mas também de outros povos: africanos, indígenas e judeus (cristãos-novos). Destarte, nesse cadinho, estes se mesclaram étnica e culturalmente, mas também mantiveram práticas religiosas tradicionais. Por decorrência, apesar de o catolicismo ter sido imposto aos outros grupos culturais como religião de Estado, única permitida, percebe-se a vivência de religiões não cristãs - tais como o criptojudaísmo ou as práticas mágico-religiosas africanas e indígenas -, além da consolidação de cultos sincréticos e mesmo da reinterpretação do catolicismo, vivido como religião que garantia direitos negados pelos senhores. Assim, se fosse avaliada a vivência religiosa nas Minas setecentistas pela diversidade das culturas envolvidas e suas representações cosmológicas, perceber-se-ia que pensá-la somente a partir do

63 APM. SC.45. Carta Régia. Lisboa, 21 de abril de 1746, f.100.

64 APM. SC.92. Carta do Rei dom José ao Governador das Minas Gomes Freire de Andrada. Lisboa, 11 de maio de $1753, \mathrm{f} .103$ 
paradigma religioso lusitano, julgá-la como homogênea, e concluir que o catolicismo teria domado o espírito de revolta e de descontentamento dos negros face à escravidão, seria uma posição no mínimo ingênua. ${ }^{65}$

Além disso, com a proibição da entrada das ordens religiosas e a inexistência do bispado até 1745, o modelo sacramental e o ensino da doutrina sofreu duro golpe, pois, distantes do cajado do bispo, muitos clérigos relaxaram nas prescrições religiosas. Preocupados com as oitavas de ouro e com os negócios seculares, muitos paroquianos ficaram sem doutrina, e os escravos sem nem mesmo os rudimentos da fé.

De forma geral, percebem-se, nas Gerais, vários embates no campo religioso: por parte das autoridades coloniais, a vontade de controlar a população versus a insubmissão de diversos agentes eclesiásticos e da comunidade, que resistia aos padrões morais vigentes após o Concílio de Trento (1545-1563). Além disso, nota-se a imposição de um movimento religioso (o catolicismo) marcado pela desigualdade social e étnica, e que dava plena legitimidade à escravidão, versus a capacidade de resistência das gens de couleur.

A religião foi pensada como instrumento de controle social: essa é uma leitura que se pode depreender da análise da documentação coeva. Contudo, deve-se tomar em conta a diversidade cultural (e religiosa) dos fiéis, e ser menos descrente em relação à capacidade de ação de seus moradores. Explorando as ambiguidades e os espaços oferecidos no meio social, os escravos interpretaram o catolicismo, souberam transformar essa instituição em um mecanismo legítimo para refazer identidades, perceber direitos e se defender dos abusos dos senhores, não perdendo, porém, sua capacidade de reação, que se expressou, inclusive, através da violência.

Nas Minas setecentistas, a vivência religiosa era múltipla, afastandose muito do esperado pela doutrina católica. Variava, entre os africanos, segundo seus universos cosmológicos, que se alteravam significativamente de acordo com as regiões de origem, tornando-se ainda mais complexos com a mestiçagem cultural. Como resultado do processo de dominação ao qual escravos, libertos e mestiços foram submetidos, vários fenômenos distintos afluíram como forma de resistência, fatos de difícil observação como a água que flui no subterrâneo e que não é percebida senão quando brota, formando pequenos "olhos d'água". ${ }^{66}$

A razão para a descrença na resistência religiosa reside na quase ausência de relatos de vida dos africanos e descendentes; na natureza da documentação disponível; ou mesmo na filiação teórico-ideológica dos

65 A esse respeito, conferir o trabalho de PAIVA, Eduardo França. Por meu trabalho, serviço e indústria: histórias de africanos, crioulos e mestiços na Colônia: Minas Gerais, 1716-1789. São Paulo: Universidade de São Paulo, 1999 (História, Tese de doutorado).

66 Ver MAFFESOLI, Michel. A transfiguração do político: a tribalização do mundo. Porto Alegre: Sulina, 1997. 
pesquisadores, que não se permitem visualizar tais formas de resistência, pois vêem o político somente na relação entre a Igreja e o Estado, não percebendo que ele também se estende à vivência religiosa - o que torna necessária uma apreensão mínima da diversidade cultural (e religiosa) dos povos submetidos à ação pastoral da Igreja. No aprofundamento dessa análise, pretende-se avançar diante das visões esquemáticas sobre o tema, que se desdobram, mas também se repetem desde os tempos coloniais. Mas não é esse, afinal, o desafio posto pela história? 